\title{
Peroxidase and Superoxide Dismutase Activities in Fig Leaves in Response to Ambient Air Pollution in a Subtropical City
}

\author{
M.-H. Li \\ Laboratory of Environmental Toxicology, Department of Geography, National Taiwan University, 1, Section 4, Roosevelt Road, Taipei, 106, Taiwan, \\ ROC
}

Received: 23 July 2002/Accepted: 18 February 2003

\begin{abstract}
Urban air pollution is a serious problem in both developing and developed countries, and antioxidant enzyme activities in plants have been suggested as a useful bioindicator of air pollution. In this study, the seasonal and spatial variability of peroxidase and superoxide dismutase activities were measured in leaves of Ficus microcarpa at eight sampling sites in the Taipei metropolitan area and one background site in rural area at each month for a year. The spatial pattern of peroxidase activity in figs collected from the Taipei metropolitan area was similar to the spatial pattern of $\mathrm{O}_{3}$ concentration in the Taipei metropolitan area. The peroxidase activities of Ficus microcarpa were significantly higher at sampling sites from the outer zone of the metropolitan area than those from the inner zone of the metropolitan area in spring and summer. On the other hand, the spatial pattern of superoxide dismutase activity in fig leaves did not show significant differences between the inner and outer zones of the Taipei metropolitan area. In addition, peroxidase activities, but not superoxide dismutase activities, of Ficus microcarpa were significantly higher in sites with high traffic density than those in low traffic density sites. Even though peroxidase activities in Ficus microcarpa tended to be higher in high traffic density sites or some sites with high ozone concentration, site-specific changes of peroxidase activity in Ficus microcarpa due to $\mathrm{O}_{3}$ pollution were not clearly observed in this study. Based on these results, neither peroxidase nor superoxide dismutase in Ficus microcarpa is a sensitive bioindicator for $\mathrm{O}_{3}$ pollution, although peroxidase shows some potential to be used as a general bioindicator of air quality.
\end{abstract}

Urban air pollution is a major environmental problem in many developing and developed countries. Thus, monitoring air pollution in urban area is becoming increasingly important with rapidly growing population, heavy vehicle traffic, and economic development. The use of plants as biomonitors for air pollution has many advantages since they integrate the effects of air pollution over a period of time, show combined effects of

Email: meihuili@ccms.ntu.edu.tw several air pollutants on plants, and provide information on potential impact of air pollution on plants. At present, a wide variety of biochemical variables in plants are used as bioindicators of air pollution (Carreras et al. 1996; Canas et al. 1997; Puccinelli et al. 1998; Ninave et al. 2001)

Many important and widespread air pollutants, such as $\mathrm{SO}_{2}$, $\mathrm{NO}_{\mathrm{x}}$, and $\mathrm{O}_{3}$, can produce an oxidative stress in plants and adversely affect physiological processes of different plants (Darrall 1989; Foyer et al. 1994; Sandermann 1996). In addition to morphological damage, responses of plants to oxidative stresses include a number of physiological and biochemical changes which are involved in both enzymatic and nonenzymatic antioxidant defense systems (Sharma and Davis 1997). It is well known that oxidative stresses increase activities of antioxidant enzymes such as superoxide dismutases, catalases and peroxidases (Hippeli and Elstner 1996; Sharma and Davis 1997). Among these antioxidant enzymes, peroxidase activity in plants was found to be a sensitive indicator of pollutant exposure (Keller 1974; Curtis et al. 1976; Sarkar et al. 1986) and has been suggested as a maker to evaluate urban air pollution (Puccinelli et al. 1998; Kammerbauer and Dick 2000). On the other hand, the role of superoxide dismutase in plants in response to air pollutants is contradictory. Increased superoxide dismutase activity from pollutant exposure was found in snapbean (Lee and Bennett 1982), pine and spruce (Tandy et al. 1989), and sugarbeet (Dixon et al. 1995). Other studies reported largely no changes of superoxide dismutase activity in plants (Nast et al. 1993; Ranieri et al. 1994; Polle et al. 1994). The usefulness of superoxide dismutase activity as an indicator of pollutant exposure still needs to be evaluated.

The present knowledge of effects of air pollution on plants is mostly based on experiments where plants have been exposed to high concentrations of air pollutants for short periods under experimental conditions (Darrall 1989; Sandermann 1996). However, less is known about responses of plants to air pollutants at environmentally relevant concentrations and for long durations in field conditions. Moreover, although responses of plants to air pollutants in temperate areas have attracted much research attention, there has been little work to study subtropical or tropical regions. In Taiwan, there is a growing air pollution problem in urban areas from a variety of human activities; and a number of air quality monitoring sites have been established to monitor air 


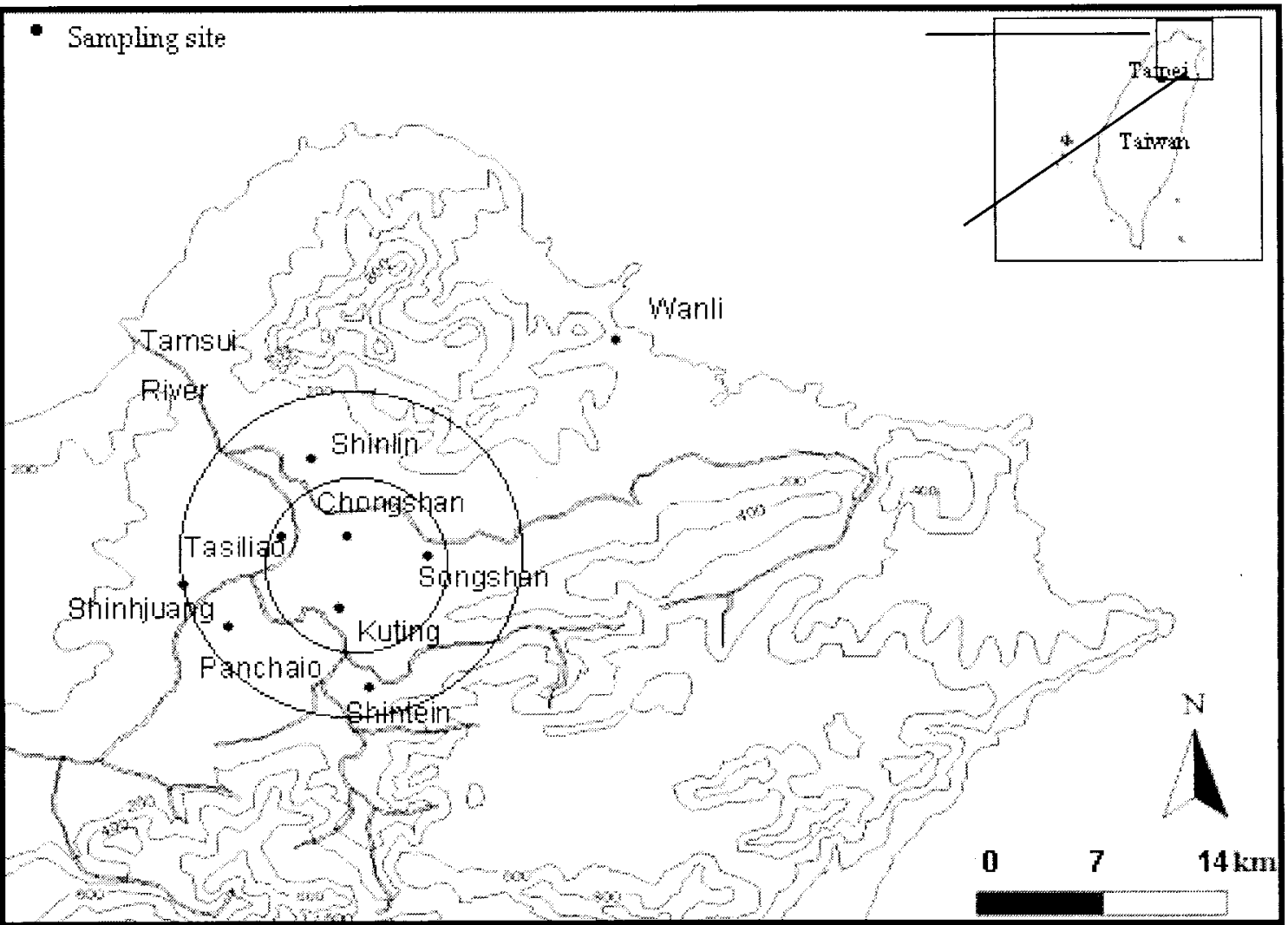

Fig. 1. Sampling sites in the Taipei metropolitan area

quality in Taiwan. However, previously there were only limited monitoring sites distributed at different locations to provide enough information on air quality in urban areas. In order to better understand the air quality in the Taipei metropolitan area, it is important to investigate the potential use of plant responses as indicators of air quality.

The objective of this study is to compare antioxidant enzyme activities in fig trees (Ficus microcarpa) from different air quality monitoring stations and to test the hypothesis that elevated antioxidant enzyme activities in foliar tissues are associated with the degree of air pollution. Peroxidase and superoxide dismutase activities were measured in leaves of Ficus microcarpa collected from eight sites with different degrees of air quality in the Taipei metropolitan area and from one background site located in a rural area. Ficus microcarpa was chosen as a study species because of its common presence in parks, school campus, roadsides and urban areas in Taiwan as well as in many parts of South and Southeast Asia.

\section{Materials and Methods}

\section{Study Areas}

The selection of sampling sites was based on the Taiwan EPA air monitoring network. Eight air monitoring stations were selected in Taipei metropolitan area, including Shinlin (25 $\left.6^{\prime} 24.3^{\prime \prime} \mathrm{N}, 121^{\circ} 30^{\prime} 23.3^{\prime \prime} \mathrm{E}\right)$, Chungshan $\left(25^{\circ} 3^{\prime} 48.88^{\prime \prime} \mathrm{N}, 121^{\circ} 31^{\prime} 4.54^{\prime \prime} \mathrm{E}\right)$, Kuting $\left(25^{\circ} 1^{\prime} 16.72^{\prime \prime} \mathrm{N}\right.$, $\left.121^{\circ} 31^{\prime} 13.49^{\prime \prime} \mathrm{E}\right)$, Tasiliao (25 $\left.3^{\prime} 51.12^{\prime \prime} \mathrm{N}, 121^{\circ} 28^{\prime} 50.41^{\prime \prime} \mathrm{E}\right)$, Shinjuang $\left(25^{\circ} 2^{\prime} 8^{\prime \prime} \mathrm{N}, 121^{\circ} 25^{\prime} 29^{\prime \prime} \mathrm{E}\right)$, Panchiao $\left(25^{\circ} 0^{\prime} 49.27^{\prime \prime} \mathrm{N}, 121^{\circ} 26^{\prime} 59.66^{\prime \prime} \mathrm{E}\right)$ Songshan $\left(25^{\circ} 3^{\prime} 7^{\prime \prime} \mathrm{N}, 121^{\circ} 34^{\prime} 12^{\prime \prime} \mathrm{E}\right)$, and Shintien $\left(24^{\circ} 58^{\prime} 43.73^{\prime \prime} \mathrm{N}, 121^{\circ}\right.$ $\left.31^{\prime} 44.54^{\prime \prime} \mathrm{E}\right)$. A background site, Wanli $\left(25^{\circ} 10^{\prime} 51.62^{\prime \prime} \mathrm{N}, 121^{\circ}\right.$ $40^{\prime} 51.71^{\prime \prime} \mathrm{E}$ ), was also included in this study (Figure 1). The hourly concentrations of air pollutants including $\mathrm{SO}_{2}, \mathrm{CO}, \mathrm{O}_{3}, \mathrm{PM}_{10}$, and $\mathrm{NO}_{\mathrm{x}}$ were continuously monitored on the campus of the selected primary or secondary school in each monitoring station. The instrumentation used in each station was ultraviolet fluorescence for $\mathrm{SO}_{2}$, nondisperse infrared absorption for $\mathrm{CO}$, ultraviolet absorption for $\mathrm{O}_{3}, \beta$-gauge for $\mathrm{PM}_{10}$, and chemiluminescence for $\mathrm{NO}_{\mathrm{x}}$. Based on the location of each sampling site, Chongshan, Kuting, Songshan, and Tasiliao were classified as sites located in the inner zone of the Taipei metropolitan area with higher $\mathrm{NO}_{\mathrm{x}}$ pollution, whereas Panchiao, Shinhtein, Shinhjuang, and Shinlin were classified as sites located in the outer zone of the Taipei metropolitan area with higher $\mathrm{O}_{3}$ pollution (Figure 1). Table 1 is a summary of characteristics of air pollution at each sampling site.

\section{Traffic Density}

Traffic counts on major roads are routinely carried out by the Department of Transportation Taipei City and Taipei County Governments once per year, for trucks, cars and motorcycles separately. The weekday counts during rush hours between $0700-0900$ and $1600-1800$ in 2000 or 2001 were used to classify traffic density in major roads at sampling sites in the present study (Table 2). Each sampling site was characterized in terms of traffic density as follows: low traffic density (Shinhtein, Shinhjuang, and Wanli); medium traffic density (Chongshan, Songshan, and Tasiliao); and high traffic density (Kuting, Panchiao, and Shinlin). 
Table 1. Monthly mean concentrations $( \pm$ SD) of air pollutants at study sites from October 2000 to September 2001

\begin{tabular}{|c|c|c|c|c|c|c|c|}
\hline Site & $\begin{array}{l}\text { Distance of site } \\
\text { from major } \\
\text { roads }(\mathrm{m})\end{array}$ & $\begin{array}{l}\text { Site location } \\
\text { classification }\end{array}$ & $\mathrm{O}_{3}(\mathrm{ppb})$ & $\mathrm{SO}_{2}(\mathrm{ppb})$ & $\mathrm{NO}_{\mathrm{x}}(\mathrm{ppb})$ & $\mathrm{CO}(\mathrm{ppm})$ & $\mathrm{PM}_{10}\left(\mu \mathrm{g} / \mathrm{m}^{3}\right)$ \\
\hline Shinhtein & 110 & outer & $24.52 \pm 0.46$ & $1.81 \pm 0.06$ & $21.65 \pm 0.86$ & $0.58 \pm 0.02$ & $35.63 \pm 1.84$ \\
\hline Shinlin & 150 & outer & $23.78 \pm 0.62$ & $2.05 \pm 0.09$ & $27.88 \pm 0.93$ & $0.74 \pm 0.02$ & $39.63 \pm 1.82$ \\
\hline Songshan & 20 & inner & $18.11 \pm 0.46$ & $3.45 \pm 0.08$ & $46.26 \pm 1.45$ & $0.86 \pm 0.02$ & $42.20 \pm 1.70$ \\
\hline Chungshan & 30 & inner & $18.71 \pm 0.42$ & $3.38 \pm 0.10$ & $46.38 \pm 1.25$ & $0.94 \pm 0.02$ & $50.84 \pm 2.57$ \\
\hline Kuting & 30 & inner & $20.41 \pm 0.46$ & $2.65 \pm 0.07$ & $42.05 \pm 1.02$ & $0.84 \pm 0.02$ & $38.78 \pm 1.76$ \\
\hline Tasiliao & 70 & inner & $19.27 \pm 0.41$ & $3.82 \pm 0.12$ & $42.99 \pm 1.25$ & $0.95 \pm 0.02$ & $51.15 \pm 2.91$ \\
\hline Shinhjuang & 200 & outer & $25.83 \pm 0.45$ & $5.11 \pm 0.21$ & $36.08 \pm 1.01$ & $0.79 \pm 0.02$ & $49.45 \pm 2.02$ \\
\hline Panchiao & 100 & outer & $20.59 \pm 0.46$ & $5.05 \pm 0.19$ & $40.61 \pm 1.09$ & $0.84 \pm 0.02$ & $49.49 \pm 2.18$ \\
\hline Wanli & 30 & remote & $35.41 \pm 1.18$ & $1.28 \pm 0.06$ & $8.41 \pm 0.34$ & $0.31 \pm 0.01$ & $40.64 \pm 1.72$ \\
\hline
\end{tabular}

Table 2. Traffic loads at study sites during 0700-0900 and 1600-1800 in 2000 or 2001

\begin{tabular}{|c|c|c|c|c|c|}
\hline $\begin{array}{l}\text { Site (sampling date of } \\
\text { traffic load) }\end{array}$ & $\begin{array}{l}\text { Traffic load } \\
\text { category }\end{array}$ & $\begin{array}{l}\text { Truck traffic } \\
\text { density (cars/hr) }\end{array}$ & $\begin{array}{l}\text { Automobile } \\
\text { traffic density } \\
\text { (cars/hr) }\end{array}$ & $\begin{array}{l}\text { Motorcycle } \\
\text { traffic density } \\
\text { (cars/hr) }\end{array}$ & $\begin{array}{l}\text { Distance of sampling } \\
\text { figs to major road } \\
\text { (m) }\end{array}$ \\
\hline Shinhtein $^{1}(8 / 17 / 2000)$ & low & 29 & 758 & 855 & 70 \\
\hline $\operatorname{Shinlin}^{2}(6 / 20 / 2001)$ & high & 107 & 1246 & 893 & 100 \\
\hline Songshan $^{2}(9 / 12 / 2001)$ & medium & 98 & 1323 & 1071 & 45 \\
\hline Chungshan ${ }^{2}(7 / 03 / 2001)$ & medium & 100 & 899 & 1994 & 30 \\
\hline Kuting $^{2}(9 / 20 / 2001)$ & high & 104 & 1384 & 2001 & 30 \\
\hline Tasiliao $^{1}(8 / 01 / 2000)$ & medium & 53 & 764 & 859 & 100 \\
\hline Shinhjuang $^{1}(8 / 04 / 2000)$ & low & 17 & 385 & 723 & 200 \\
\hline Panchiao $^{1}(9 / 14 / 2000)$ & high & 170 & 1334 & 1556 & 100 \\
\hline $\operatorname{Wanli}^{1}(8 / 31 / 2000)$ & low & 43 & 400 & 115 & 2 \\
\hline
\end{tabular}

${ }^{1}$ Traffic load data source: Department of Transportation, Taipei County Government.

${ }^{2}$ Traffic load data source: Department of Transportation, Taipei City Government.

\section{Field Collection}

Leaves of Ficus microcarpa were collected at each sampling site between 0930 to 1300 once per month from October 2000 to September 2001. Trees of approximately the same height and similar trunk girth were selected within a distance of $150 \mathrm{~m}$ from each air monitoring station, and three such trees of Ficus microcarpa without any visible injury were chosen at each site. For each sampling tree, leaves were collected in four directions at approximately $1.5-2.5 \mathrm{~m}$ high. Leaves were immediately stored in a portable cooler upon collection until transport back to the laboratory. Then the leaves were immediately washed, weighed and stored in liquid nitrogen $\left(-180^{\circ} \mathrm{C}\right)$ until analysis. Effects of storage in a cooler during field collection did not alter peroxidase activities of Ficus microcarpa, as assessed by a separate experiment (data not shown).

\section{Enzyme Assays}

Frozen leaves $(4 \mathrm{~g})$ were homogenized in $35 \mathrm{~mL}$ of $0.1 \mathrm{M}$ potassium phosphate buffer $(\mathrm{pH} 7.0)$ at $4^{\circ} \mathrm{C}$, and the homogenates were filtered and centrifuged at $15,500 \mathrm{~g}$ for $30 \mathrm{~min}$ at $4^{\circ} \mathrm{C}$. The supernatant was then stored in liquid nitrogen until analysis. The activity of peroxidase was determined spectrophotometrically according to the method of Angelini and Federico (1989). The reaction mixture consisted of $0.1 \mathrm{M}$ potassium phosphate buffer ( $\mathrm{pH}$ 7.0), $5 \mathrm{mM}$ guaiacol, and $2 \mathrm{mM} \mathrm{H}_{2} \mathrm{O}_{2}$. The reaction was initiated by the addition of plant extract. Enzyme activity was determined by measuring the change in absorbance at 470 $\mathrm{nm}$ (extinction coefficient of $26.6 \mathrm{mM}^{-1} \mathrm{~cm}^{-1}$ ) in $3 \mathrm{~min}$ at $25^{\circ} \mathrm{C}$ and expressed as units per g leaf fresh weight. The activity of superoxide dismutase was assayed spectrophotometrically by measuring the inhibition of photochemical reduction of nitroblue tetrazolium (NBT), according to the method of Dhindsa et al. (1981) and Abassi et al. (1998) with slight modifications. The $1.5 \mathrm{~mL}$ reaction mixture contained $50 \mathrm{mM} \mathrm{KPO}_{4}$ buffer ( $\mathrm{pH} 7.8$ ), $13 \mathrm{mM}$ methionine, $75 \mu \mathrm{M} \mathrm{NBT}$, $0.1 \mathrm{mM}$ EDTA, and $2 \mu \mathrm{M}$ riboflavin and $0-50 \mu \mathrm{L}$ enzyme extract. The reaction mixtures were placed approximately $15 \mathrm{~cm}$ below $15-\mathrm{W}$ fluorescent lamps, and illuminated for $10 \mathrm{~min}$. One unit of superoxide dismutase activity was defined as the amount of enzyme required to cause $50 \%$ inhibition of the reduction of NBT, as monitored at $560 \mathrm{~nm}$ in a $1.5 \mathrm{~mL}$ assay volume. Superoxide dismutase activity was expressed as units per $g$ leaf fresh weight. Protein content was determined by the modification of the Lowry method reported by Guengerich (1982) using bovine serum albumin as a standard.

\section{Data Analysis}

All samples were analyzed in duplicate and data were expressed as means \pm standard deviation (SD). The data were analyzed by one-way or two-way ANOVAs using the Minitab statistical program (Release 13.2). For two-way ANOVA, the main effect means were sampling sites and sampling seasons, and one interaction (site $\times$ season) was tested. If a significant result was found, Tukey's multiple comparison test was used to compare all pairs of different sites or periods. Differences were considered significant if $p \leq 0.05$. 
Table 3. Comparisons of air pollutants $( \pm$ SD) among different sampling locations from October 2000 to September 2001

\begin{tabular}{|c|c|c|c|c|}
\hline & \multicolumn{3}{|l|}{ Sampling location } & \multirow[b]{2}{*}{$p$} \\
\hline & Inner zone ( $n=4$ sites) & Outer zone ( $n=4$ sites) & Remote ( $n=1$ site $)$ & \\
\hline \multicolumn{5}{|l|}{$\mathrm{O}_{3}(\mathrm{ppb})$} \\
\hline spring & $23.0 \pm 1.1^{\mathrm{A} 1}$ & $27.5 \pm 2.6^{\mathrm{B}}$ & $42.9 \pm 2.0^{C}$ & $<0.0005$ \\
\hline summer & $18.3 \pm 1.7^{\mathrm{A}}$ & $22.7 \pm 2.7^{\mathrm{B}}$ & $24.5 \pm 2.7^{\mathrm{B}}$ & $<0.0005$ \\
\hline fall & $17.4 \pm 1.5^{\mathrm{A}}$ & $22.0 \pm 3.0^{\mathrm{B}}$ & $37.1 \pm 0.8^{C}$ & $<0.0005$ \\
\hline winter & $17.7 \pm 1.7^{\mathrm{A}}$ & $22.5 \pm 2.7^{\mathrm{B}}$ & $37.1 \pm 1.3^{\mathrm{C}}$ & $<0.0005$ \\
\hline \multicolumn{5}{|l|}{$\mathrm{NO}_{\mathrm{x}}(\mathrm{ppb})$} \\
\hline spring & $50.1 \pm 7.7^{\mathrm{A}}$ & $37.5 \pm 10.1^{\mathrm{B}}$ & $9.4 \pm 0.5^{\mathrm{C}}$ & $<0.0005$ \\
\hline summer & $38.2 \pm 4.1^{\mathrm{A}}$ & $28.3 \pm 8.3^{\mathrm{B}}$ & $10.4 \pm 1.4^{\mathrm{C}}$ & $<0.0005$ \\
\hline fall & $40.6 \pm 5.3^{\mathrm{A}}$ & $27.4 \pm 6.7^{\mathrm{B}}$ & $5.8 \pm 0.2^{\mathrm{C}}$ & $<0.0005$ \\
\hline winter & $48.8 \pm 5.5^{\mathrm{A}}$ & $33.0 \pm 8.7^{\mathrm{B}}$ & $8.1 \pm 1.7^{\mathrm{C}}$ & $<0.0005$ \\
\hline \multicolumn{5}{|l|}{$\mathrm{SO}_{2}(\mathrm{ppb})$} \\
\hline spring & $3.8 \pm 0.6^{\mathrm{A}}$ & $4.0 \pm 1.8^{\mathrm{A}}$ & $1.3 \pm 0.4^{\mathrm{B}}$ & $<0.0005$ \\
\hline summer & $3.3 \pm 0.6^{\mathrm{A}}$ & $4.1 \pm 2.3^{\mathrm{A}}$ & $1.7 \pm 0.3^{\mathrm{B}}$ & $<0.0005$ \\
\hline fall & $3.0 \pm 0.5^{\mathrm{A}}$ & $2.8 \pm 1.3^{\mathrm{A}}$ & $0.9 \pm 0.2^{\mathrm{B}}$ & $<0.0005$ \\
\hline winter & $3.2 \pm 0.8^{\mathrm{A}}$ & $3.1 \pm 1.4^{\mathrm{A}}$ & $1.2 \pm 0.1^{\mathrm{B}}$ & $<0.0005$ \\
\hline
\end{tabular}

${ }^{1}$ Values within a row with different superscripts are significantly different by Tukey's multiple comparison test $(p \leq 0.05)$

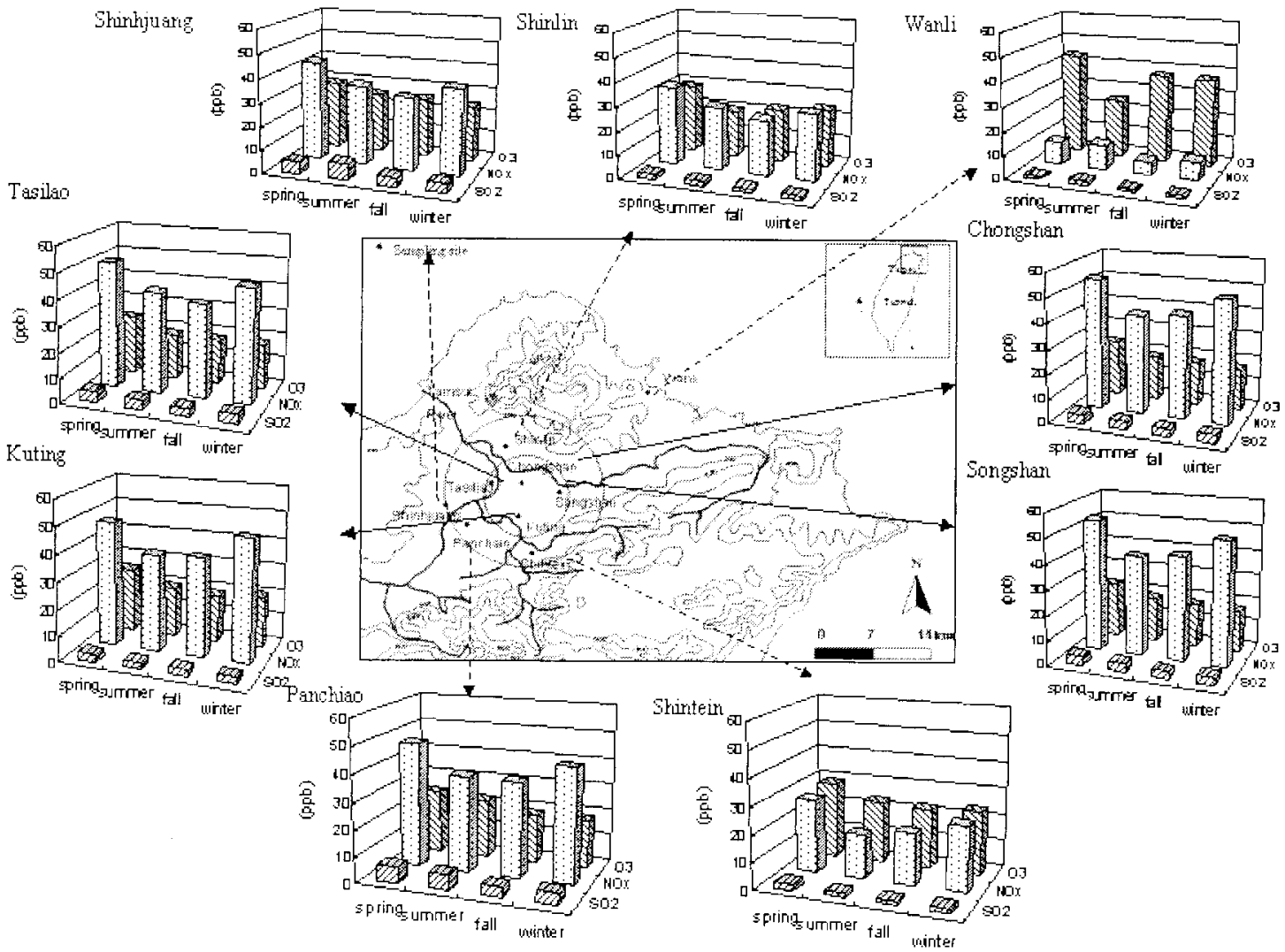

Fig. 2. Mean seasonal concentrations of $\mathrm{SO}_{2}, \mathrm{NO}_{\mathrm{x}}$, and $\mathrm{O}_{3}$ at each study site from October 2000 to September 2001

\section{Results}

\section{Characteristics of Ambient Air Pollution at Sampling Sites}

As expected, the mean monthly concentrations of $\mathrm{NO}_{\mathrm{x}}$ in the Taipei metropolitan area were higher in the central locations of the urban area than in the outer zone of the urban area, whereas mean monthly concentrations of $\mathrm{O}_{3}$ were higher in the outer zones of the urban area than at the inner zone of the urban area for all seasons (Table 3). On the other hand, the spatial pattern of $\mathrm{PM}_{10}$ and $\mathrm{SO}_{2}$ in the Taipei metropolitan area did not show any significant difference between the central and marginal locations of the Taipei metropolitan area (Tables 1 and 3). Mean monthly concentrations of $\mathrm{SO}_{2}$ were highest at Panchaio 


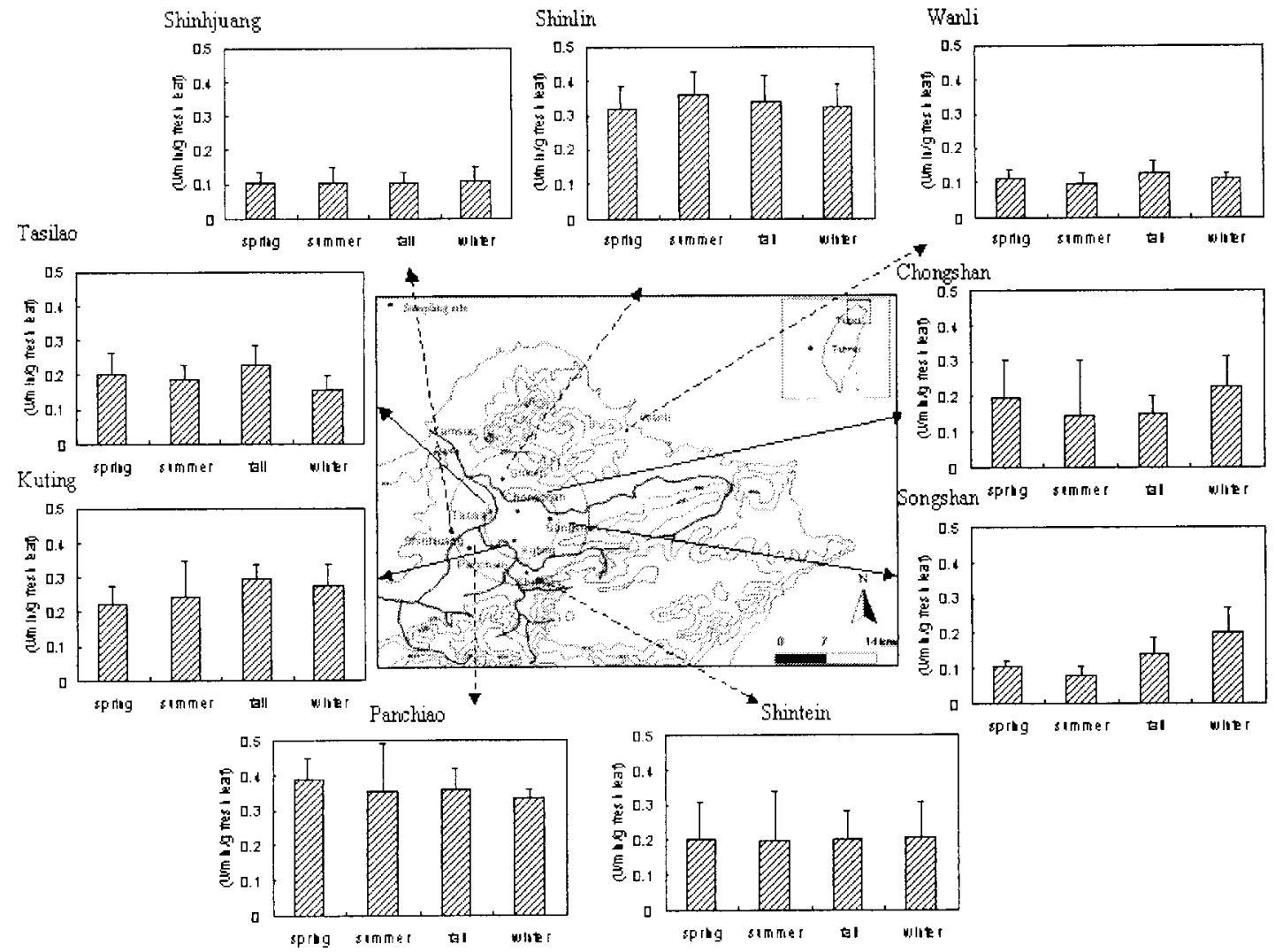

Fig. 3. Peroxidase activity (mean $\pm \mathrm{SD}$ ) of Ficus microcarpa at each study site in different seasons

during winter and spring, and at Shinhjuang during summer and fall (Figure 2). Mean monthly concentrations of $\mathrm{NO}_{\mathrm{x}}$ were highest at Chongshan during spring and summer, and highest at Songshan during fall and winter (Figure 2). The mean monthly concentrations of $\mathrm{O}_{3}$ were highest at Shinhjuang in the Taipei metropolitan area during spring, summer and fall, and at Shinlin during winter (Figure 2). The mean monthly concentration of $\mathrm{CO}, \mathrm{SO}_{2}$, and $\mathrm{NO}_{\mathrm{x}}$ was lowest in Wanli among all study sites. On the other hand, the mean monthly concentration of $\mathrm{O}_{3}$ at Wanli was highest among all study sites, although there was no obvious pollution source contributing to ozone production at this site.

\section{Seasonal Variation of Antioxidant Enzyme Activities in Fig Leaves}

There was no significant difference in peroxidase activities of Ficus microcarpa for all sites among different seasons ( $p=$ 0.666 , Figure 3 ). On the other hand, there were significant differences in protein content $(p<0.0005)$ and superoxide dismutase activity $(p<0.0005)$ of Ficus microcarpa in different seasons. In general, superoxide dismutase activity of Ficus microcarpa was highest during summer and lowest during winter (Figure 4), whereas protein content was lowest during fall in most study sites (Figure 5). There was no interaction found between sampling seasons and sites for protein contents, peroxidase and superoxide dismutase activities of Ficus microcarpa ( $p=0.257,0.082$, and 0.841 , respectively).

\section{Geographic Variation of Antioxidant Enzyme Activities in Fig Leaves}

The peroxidase activities of Ficus microcarpa were significantly higher at sampling sites in the outer zone of the metropolitan area than those in the inner zone of the metropolitan area during spring and summer (Table 4). On the other hand, there were no significant differences in either protein content or superoxide dismutase activity of Ficus microcarpa between the inner and outer zones of the metropolitan area (Table 4). In addition, peroxidase activity of Ficus microcarpa from Wanli, a background site, was the lowest compared to those from the metropolitan area, whereas superoxide dismutase activities of Ficus microcarpa form this site was the second highest compared to those from the Taipei metropolitan area.

\section{Comparison of Antioxidant Enzyme Activities in Fig Leaves Based on Traffic Density}

There were significant differences in peroxidase activity of Ficus microcarpa in sites with different traffic density $(p<$ $0.0005)$. The peroxidase activities of Ficus microcarpa were 


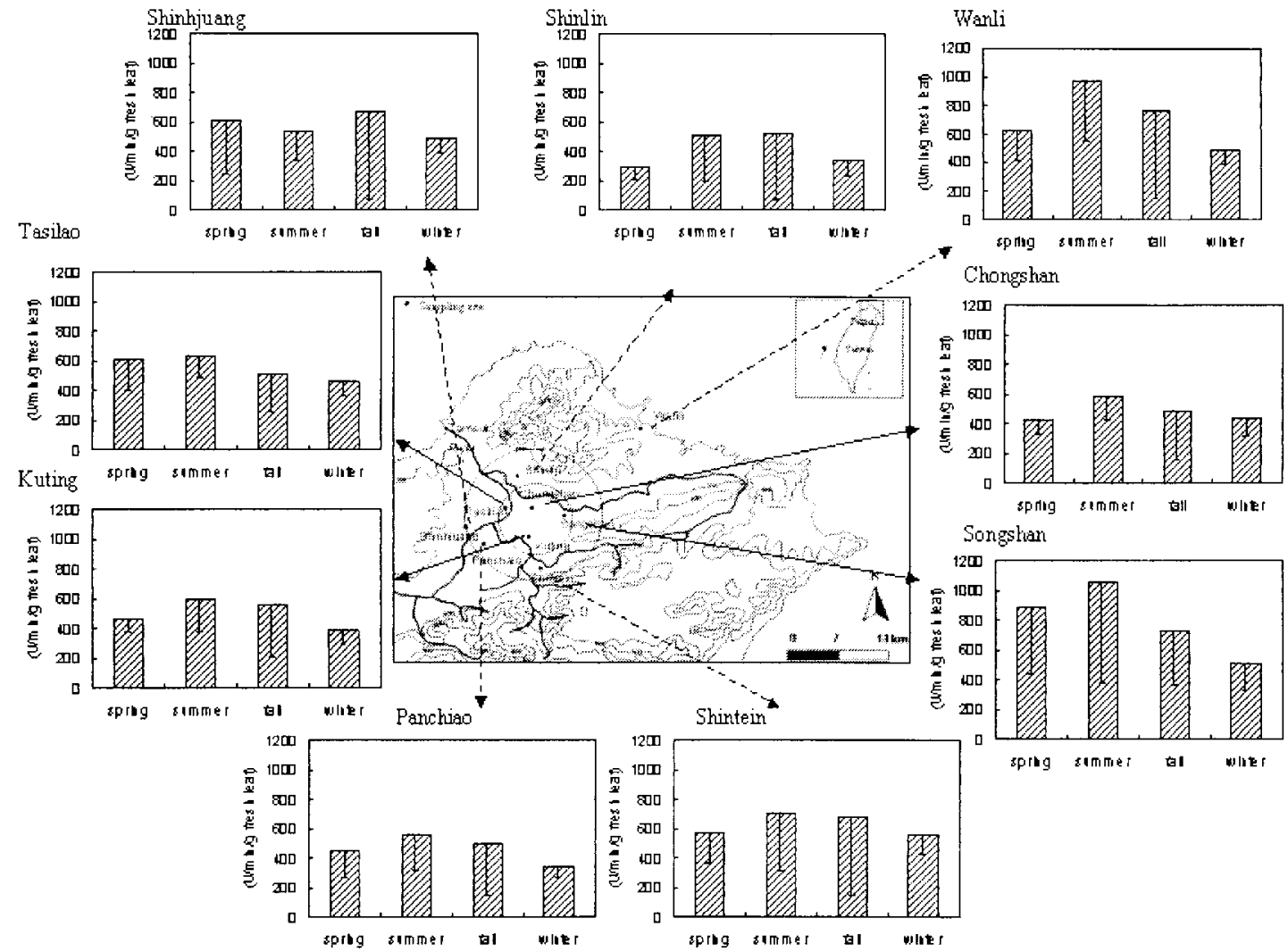

Fig. 4. Superoxide dismutase activity (mean $\pm \mathrm{SD}$ ) of Ficus microcarpa at each study site in different seasons

highest at high traffic density sites and lowest at low traffic density sites for all seasons (Table 5). There were also significant differences in superoxide dismutase activities of Ficus microcarpa in sites with different traffic density sites in spring and winter, but not in summer and fall. During spring and winter, superoxide dismutase activities of Ficus microcarpa were significantly higher at low and medium traffic density sites than at high traffic density sites (Table 5). In contrast, protein contents in fig leaves were significantly higher at high traffic density sites than at low traffic density sites during summer and fall (Table 5).

\section{Discussion}

The current study investigated the potential of antioxidant enzyme activities of Ficus microcarpa as bioindicators in response to ambient air pollution in the Taipei metropolitan area. The spatial pattern of air pollution in the Taipei metropolitan area is marked by high $\mathrm{NO}_{\mathrm{x}}$ and low $\mathrm{O}_{3}$ levels in the inner zone of the urban area, gradually changing to low $\mathrm{NO}_{x}$ and high $\mathrm{O}_{3}$ levels in the outer zone due to geomorphologic and weather factors in the Taipei basin (Liu 1994; Hung and Wang 1999; Li and Lin 2001). In this study, peroxidase activities of Ficus microcarpa were significantly higher at sampling sites from the outer zone of the metropolitan area than those from the inner zone of the metropolitan area in three seasons. On the other hand, the spatial pattern of superoxide dismutase activity in figs did not show significant difference between the inner and outer zones of the Taipei metropolitan area. In addition, peroxidase activities, but not superoxide dismutase activities, of Ficus microcarpa were significantly higher in the high traffic density sites than in low traffic density sites.

Plants respond to $\mathrm{SO}_{2}, \mathrm{NO}_{\mathrm{x}}$, and $\mathrm{O}_{3}$ pollution by activating a number of antioxidant enzyme activities to protect plants against oxidative stress (Hippeli and Elstner 1996). In general, plants produce $\mathrm{O}_{2}{ }^{-}$and $\mathrm{H}_{2} \mathrm{O}_{2}$ in chloroplasts and mitochondria during their normal aerobic metabolism, as well as under environmentally induced oxidative stress (Sharma and Davis 1997). There are several biochemical defense systems in plants to remove these harmful reactive oxygen species. For example, superoxide dismutases will dismutate $\mathrm{O}_{2}{ }^{-}$into $\mathrm{H}_{2} \mathrm{O}_{2}$ and $\mathrm{O}_{2}$. Then, peroxidases and catalases further reduce $\mathrm{H}_{2} \mathrm{O}_{2}$ into $\mathrm{H}_{2} \mathrm{O}$ and $\mathrm{O}_{2}$ (Harris 1992; Sharma and Davis 1997). Therefore, induction of antioxidant enzyme activity is proposed to be an important defense mechanism in plants in response to air pollutant-induced oxidative stress (Hippeli and Elstner 1996; Sharma and Davis 1997). In fact, the literature published on foliar antioxidant enzymes in response to air pollution is still contradictory. In this study, peroxidase activities, but not superoxide dismutase activities, of Ficus microcarpa were significantly higher in high traffic density sites than in low traffic density sites. And peroxidase activities, but not superoxide dismutase activities, were significantly higher at sampling sites from the outer zone of the metropolitan area than those from the inner zone of the metropolitan area for all seasons. Indeed, 


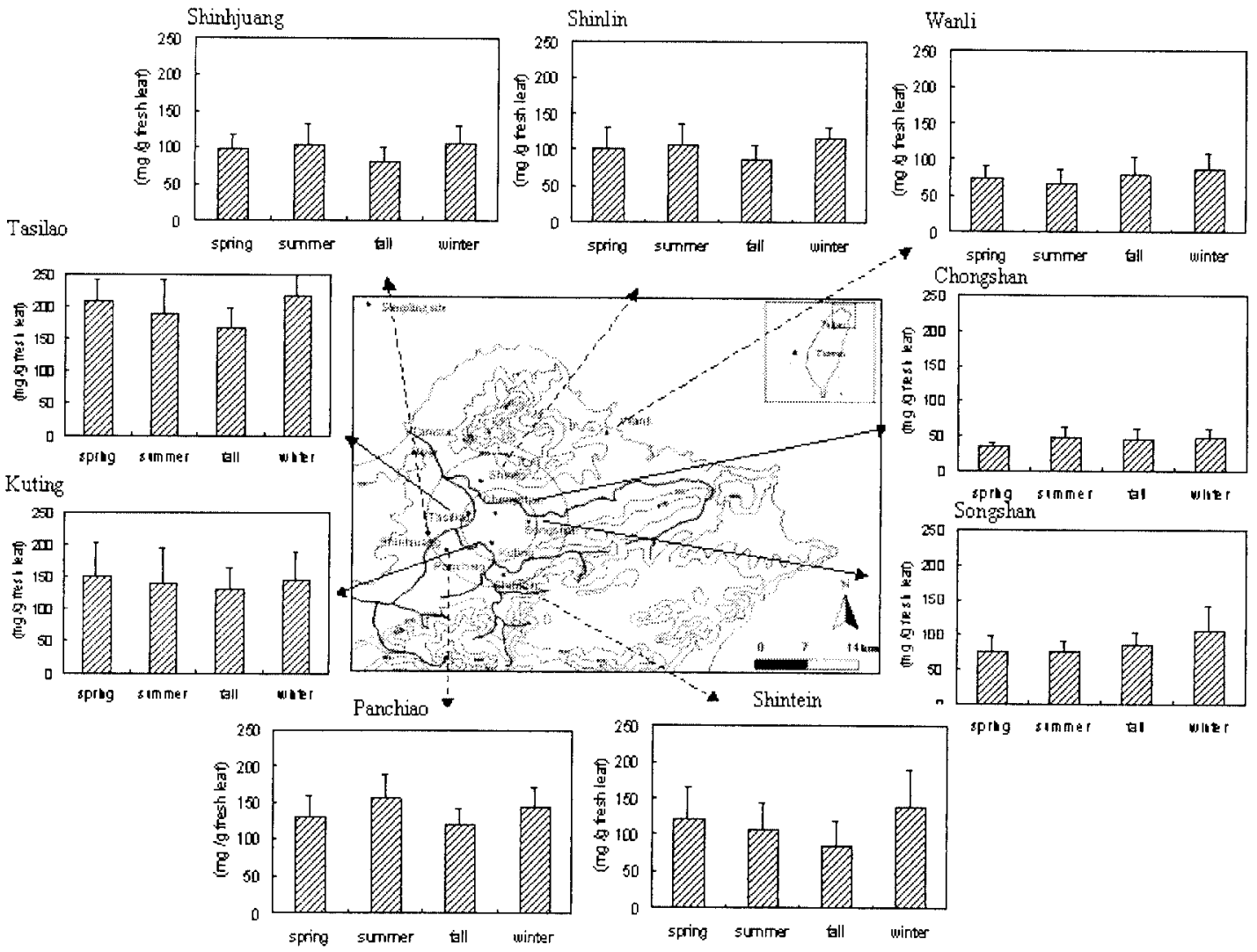

Fig. 5. Protein content (mean $\pm \mathrm{SD}$ ) of Ficus microcarpa at each study site in different seasons

Table 4. Comparison of antioxidant enzyme activities $( \pm$ SD) in Ficus microcarpa from different sites based on geographical location from October 2000 to September $2001^{1}$

\begin{tabular}{|c|c|c|c|c|}
\hline & \multicolumn{3}{|l|}{ Sampling location } & \multirow[b]{2}{*}{$p$} \\
\hline & Inner zone ( $n=4$ sites) & Outer zone ( $n=4$ sites) & Remote ( $n=1$ site) & \\
\hline \multicolumn{5}{|c|}{ Peroxidase $(\mathrm{U} / \mathrm{min} / \mathrm{g}$ ) } \\
\hline spring & $0.183 \pm 0.077^{\mathrm{A}}$ & $0.255 \pm 0.130^{\mathrm{B}}$ & $0.111 \pm 0.027^{\mathrm{A}}$ & $<0.0005$ \\
\hline summer & $0.166 \pm 0.110^{\mathrm{A}}$ & $0.255 \pm 0.150^{\mathrm{B}}$ & $0.096 \pm 0.034^{\mathrm{A}}$ & 0.001 \\
\hline fall & $0.204 \pm 0.078^{\mathrm{AB}}$ & $0.252 \pm 0.123^{\mathrm{B}}$ & $0.126 \pm 0.035^{\mathrm{A}}$ & 0.003 \\
\hline winter & $0.215 \pm 0.076^{\mathrm{A}}$ & $0.243 \pm 0.113^{\mathrm{A}}$ & $0.114 \pm 0.015^{\mathrm{B}}$ & 0.001 \\
\hline \multicolumn{5}{|c|}{ Superoxide dismutase $(\mathrm{U} / \mathrm{min} / \mathrm{g})$} \\
\hline spring & $595 \pm 302$ & $483 \pm 252$ & $625 \pm 206$ & 0.152 \\
\hline summer & $713 \pm 402^{\mathrm{A}}$ & $577 \pm 287^{\mathrm{A}}$ & $969 \pm 425^{\mathrm{B}}$ & 0.013 \\
\hline fall & $572 \pm 327$ & $590 \pm 467$ & $762 \pm 613$ & 0.488 \\
\hline winter & $449 \pm 130$ & $432 \pm 137$ & $483 \pm 101$ & 0.558 \\
\hline \multicolumn{5}{|c|}{ Protein $(\mathrm{mg} / \mathrm{g})$} \\
\hline spring & $118.1 \pm 73.5$ & $112.9 \pm 33.2$ & $73.9 \pm 17.9$ & 0.095 \\
\hline summer & $113.9 \pm 67.3^{\mathrm{A}}$ & $117.7 \pm 38.2^{\mathrm{A}}$ & $66.9 \pm 21.4^{\mathrm{B}}$ & 0.034 \\
\hline fall & $107.4 \pm 52.0$ & $92.8 \pm 28.3$ & $80.3 \pm 23.0$ & 0.124 \\
\hline winter & $129.3 \pm 69.5$ & $126.4 \pm 34.5$ & $86.9 \pm 21.8$ & 0.092 \\
\hline
\end{tabular}

${ }^{1}$ Values within a row with different superscripts are significantly different by Tukey's multiple comparison test $(p \leq 0.05)$.

several field studies have shown that superoxide dismutase activity failed to increase in response to air pollution. For example, Nast et al. (1993) found that superoxide dismutase activity in Norway spruce did not change when exposed in the open-top chambers with different air pollutant combinations, whereas peroxidase activity of Norway spruce increased in all treatments. Ranieri et al. (1994) reported that superoxide dismutase activity in pumpkin plants did not change with exposure to polluted air, whereas peroxidase activity in pumpkin plants increased with polluted air. Polle et al. (1994) observed no increase of superoxide dismutase activity in needles of Scotch pine from $\mathrm{SO}_{2}$-polluted sites in eastern Germany. Cal- 
Table 5. Comparison of antioxidant enzyme activities $( \pm \mathrm{SD})$ in Ficus microcarpa from different sites based on traffic density from October 2000 to September $2001^{1}$

\begin{tabular}{|c|c|c|c|c|}
\hline & \multicolumn{3}{|c|}{ Degree of traffic density } & \multirow[b]{2}{*}{$p$} \\
\hline & $\operatorname{High}(n=3$ sites $)$ & Medium ( $n=3$ sites) & Low $(n=3$ sites $)$ & \\
\hline \multicolumn{5}{|c|}{ Peroxidase (U/min/g) } \\
\hline Spring & $0.310 \pm 0.090^{\mathrm{A}}$ & $0.171 \pm 0.080^{\mathrm{B}}$ & $0.140 \pm 0.078^{\mathrm{B}}$ & $<0.0005$ \\
\hline Summer & $0.321 \pm 0.114^{\mathrm{A}}$ & $0.140 \pm 0.101^{\mathrm{B}}$ & $0.133 \pm 0.098^{\mathrm{B}}$ & $<0.0005$ \\
\hline Fall & $0.332 \pm 0.064^{\mathrm{A}}$ & $0.174 \pm 0.062^{\mathrm{B}}$ & $0.145 \pm 0.068^{\mathrm{B}}$ & $<0.0005$ \\
\hline Winter & $0.311 \pm 0.057^{\mathrm{A}}$ & $0.195 \pm 0.071^{\mathrm{B}}$ & $0.143 \pm 0.078^{\mathrm{C}}$ & $<0.0005$ \\
\hline \multicolumn{5}{|c|}{ Superoxide dismutase (U/min/g) } \\
\hline Spring & $404 \pm 147^{\mathrm{A}}$ & $641 \pm 334^{\mathrm{B}}$ & $601 \pm 257^{\mathrm{B}}$ & 0.003 \\
\hline Summer & $552 \pm 247$ & $755 \pm 444$ & $737 \pm 380$ & 0.084 \\
\hline Fall & $525 \pm 366$ & $577 \pm 328$ & $701 \pm 552$ & 0.306 \\
\hline Winter & $358 \pm 94^{\mathrm{A}}$ & $469 \pm 135^{\mathrm{B}}$ & $509 \pm 111^{\mathrm{B}}$ & $<0.0005$ \\
\hline \multicolumn{5}{|c|}{ Protein $(\mathrm{mg} / \mathrm{g})$} \\
\hline Spring & $127.7 \pm 41.2$ & $107.2 \pm 77.5$ & $97.7 \pm 34.8$ & 0.126 \\
\hline Summer & $133.8 \pm 44.7^{\mathrm{A}}$ & $105.4 \pm 69.6^{\mathrm{AB}}$ & $91.9 \pm 34.2^{\mathrm{B}}$ & 0.013 \\
\hline Fall & $112.4 \pm 30.6^{\mathrm{A}}$ & $99.8 \pm 55.2^{\mathrm{AB}}$ & $81.5 \pm 25.6^{\mathrm{B}}$ & 0.018 \\
\hline Winter & $135.5 \pm 32.5$ & $124.0 \pm 76.1$ & $110.4 \pm 39.9$ & 0.226 \\
\hline
\end{tabular}

${ }^{1}$ Values within a row with different superscripts are significantly different by Tukey's multiple comparison test $(p \leq 0.05)$.

atayud and Barreno (2001) also showed that there was a significant reduction of superoxide dismutase activity in ozoneexposed tomato. Little is known about factors that regulate the inhibition of superoxide dismutase in plants. One possible mechanism is that $\mathrm{H}_{2} \mathrm{O}_{2}$ has been shown to decrease superoxide dismutase activity in plants (Wingsle and Hällgren 1993). In this study, inhibition of superoxide dismutase by $\mathrm{H}_{2} \mathrm{O}_{2}$ may partially explain the observed decreases of superoxide dismutase activity in Ficus microcarpa due to the presence of higher peroxidase activity in those plants. Further investigation will be needed to understand the biochemical pathway to regulate superoxide dismutase.

Peroxidase activity has been suggested as a sensitive indicator of ozone pollution (Curtis et al. 1976; Sarkar et al. 1986; Puccinelli et al. 1998); but site-specific changes of the peroxidase activity in Ficus microcarpa due to $\mathrm{O}_{3}$ pollution were not clearly observed in the present study. For example, peroxidase activity of Ficus microcarpa was high at Shinlin with high ozone concentrations, but was relatively low at Wanli with the highest ozone pollution. In fact, high peroxidase activity observed in this study cannot be attributed to ozone pollution alone in each study site. Several researchers have suggested that peroxidase activity may not be used as a specific indicator of single air pollutant and can only be considered as a general indicator of oxidative stress (Nyman 1986; Roitto et al. 1999). Moreover, oxidation products generated from free radial reactions, such as aldehydes, have been suggested as useful biomarkers of $\mathrm{O}_{3}$ exposure (Pryor et al. 1996) or $\mathrm{NO}_{2}$ exposure (Robison et al. 1996). It will be a subject for future study to measure both antioxidant enzyme activities and those oxidation products simultaneously in order to better understand oxidative stress responses on plants. The results observed in this study may be partially explained by the fact that figs collected from different sites represented various combinations of different air pollutants as well as external environmental factors. A further limitation to this study is that concentrations of air pollutants were collected by an air sampler on the top of a building between 15 to $28 \mathrm{~m}$ in height at each site in the Taiwan EPA air quality network system, not measured directly from locations of sampling figs at each site. Therefore, air pollutant concentrations reported in each site may not exactly reflect air quality of surface condition at each sampling fig location.

Variation in peroxidase activity with season has been documented in several tree species at middle latitudes. Puccinelli et al. (1998) found that peroxidase activity in several tree species in Turin, an urban area, were highest in December with high air pollution caused by road traffic and domestic heating, and low in August with air pollution caused by road traffic only. Calzada et al. (2001) showed that the peroxidase activity of Pinus radiata was generally higher in June than in September in a rural-forested area of northern Spain. At subarctic polluted sites, total peroxidase activity of Pinus sylvestris from an industrial center of Monchegorsk in northwestern Russia showed a clear relationship to the pollution gradient in winter compared to autumn (Roitto et al. 1999). However, peroxidase activities of Ficus microcarpa did not show any significantly seasonal variation in the present study, whereas superoxide dismutase activities of Ficus microcarpa were usually the lowest during winter. The lack of seasonal variation of peroxidase activity in Ficus microcarpa may be partially related to external environmental factors in the subtropical area, such as no change in emission sources in different seasons.

In conclusion, peroxidase activities of Ficus microcarpa were correlated more closely with traffic density, whereas superoxide dismutase activities of Ficus microcarpa were negatively affected by traffic density in winter and spring in the Taipei metropolitan area. Protein contents of Ficus microcarpa were only slightly affected by traffic density in summer and fall in the Taipei metropolitan area. However, a site-specific relationship between $\mathrm{O}_{3}$ level and peroxidase in Ficus microcarpa was not clearly observed at this study. Based on the present results, neither peroxidase nor superoxide dismutase in Ficus microcarpa is a sensitive bioindicator for $\mathrm{O}_{3}$ pollution, although peroxidase shows some potential to be used as a general bioindicator of air quality. It is important in the future study to examine interactions of different types of air pollutants, as well 
as other environmentally induced oxidative stress on effects of peroxidase activity in plants, before this enzyme can be effectively used as an indicator of ambient air pollution.

Acknowledgments. The author is grateful to Mr. Guan-Ru Lin for his assistance in field collection and laboratory assistance and to Ms. Chia-Chin Hsu for her technical support in figure drawing. The author greatly acknowledges the Department of Geography at National Taiwan University for providing laboratory space and equipment.

\section{References}

Abassi NA, Kushad MM, Endress AG (1998) Active oxygen-scavenging enzyme activities in developing apple flowers and fruits. Sci Hortic 74:184-194

Angelini R, Federico R (1989) Histochemical evidence of polyamine oxidation and generation of hydrogen peroxide in the cell wall. $\mathrm{J}$ Plant Physiol 135:212-217

Calatayud A, Barreno E (2001) Chlorophyll a fluorescence, antioxidant enzymes and lipid peroxidation in tomato in response to ozone and benomyl. Envion Pollut 115:283-289

Calzada I, Mesanza J, Casado, H, Castillo FJ (2001) Biochemical changes in needles of Pinus radiata D. Don trees in relationship to long-term ozone exposure indices. Environ Pollut 114:325-335

Canas MS, Carreras HA, Orellana L, Pignata ML (1997) Correlation between environmental conditions and foliar chemical parameters in Ligustrum lucidum Ait. exposed to urban air pollutants. J Environ Manag 49:167-181

Carreras HA, Canas MS, Pignata ML (1996) Differences in responses to urban air pollutants by Ligustrum lucidum Ait. and Ligustrum Lucidum Ait. f. Tricolor (Rehd.) Rehd. Environ Pollut 93:211218

Curtis CR, Howell RK, Kremer DF (1976) Soybean peroxidase from ozone injury. Environ Pollut 11:189-194

Darrall NM (1989) The effect of air pollutants on physiological processes in plants. Plant Cell Environ 12:1-30

Dhindsa RS, Plumb-Dhindsa P, Thrope TA (1981) Leaf senescence: correlated with increased levels of membrane permeability and lipid peroxidation and decreased levels of superoxide dismutase and catalase. J Exp Bot 32:93-101

Dixon J, Hull MR, Cobb AH, Sanders GE (1995) Ozone pollution modifies the response of sugarbeet to the herbicide phenmedipham. Water Air Soil Pollut 85:1443-1448

Foyer CH, Lelandais M, Kunert KJ (1994) Photooxidative stress in plants. Physiol Plant 92:696-717

Guengerich FP (1982) Microsomal enzymes involved in toxicologyanalysis and separation. In: Hayes AW (ed) Principles and methods of toxicology. Raven Press, New York, p 609

Harris ED (1992) Regulation of antioxidant enzymes. FASEB J 6:2675-2683

Hippeli S, Elstner EF (1996) Mechanisms of oxygen activation during plant stress: Biochemical effects of air pollutants. J Plant Physiol 148:249-257

Hung H-F, Wang C-S (1999) [Variations of ambient ozone concentrations in Taiwan: Application of 1- and 8-hour standards in the examination of the ozone pollution problem.] Chin J Public Health (Taipei) 18:423-431 (in Chinese with English abstract)

Kammerbauer J, Dick T (2000) Monitoring of urban traffic emission using some physiological indicators in Ricinuc communis L. plants. Arch Environ Contam Toxicol 39:161-166

Keller TH (1974) The use of peroxidase activity for monitoring and mapping air pollution areas. Eur J Forest Path 4:11-19

Lee EH, Bennett JH (1982) Superoxide dismutase, a possible protective enzyme against ozone injury in snap beans (Phaseolus vulgaris L.) Plant Physiol 67:347-350

Li P-W, Lin J-M (2001) [The diurnal variation of ozone in Taipei city.] Taiwan J Public Health 20:131-142 (in Chinese with English abstract)

Liu C-M (1994) [Serious surface ozone pollution in Taiwan.] China Environ Protection 21/22:79-87 (in Chinese)

Nast W, Mortensen L, Fisch K, Fitting I (1993) Effects of air pollutants on the growth and antioxidative system of Norway spruce exposed in open-top chambers. Environ Pollut 80:85-90

Ninave SY Chaudhari PR, Gajghate DG, Tarar JL (2001) Foliar biochemical features of plants as indicators of air pollution. Bull Environ Contam Toxicol 67:133-140

Nyman BF (1986) Industrial air pollution and peroxidase activity in Scotch pine needles-Two case studies. Eur J Forest Path 16: 139-147

Polle A, Eiblmeier M, Rennenberg H (1994) Sulphate and antioxidants in needles of Scotch pine (Pinus sylvestris L.) from three SO2polluted filed sites in eastern Germany. New Phytol 127:571-577

Pryor WA, Bermudez E, Cueto R, Squadrito GL (1996) Detection of aldehydes in bronchoalveolar lavage of rats exposed to ozone. Fund Appl Toxicol 34:148-156

Puccinelli P, Anselmi N, Bragaloni M (1998) Peroxidases: Usable markers of air pollution in trees from urban environments. Chemosphere 36:889-894

Ranieri A, Schenone G, Lencioni L, Soldatini GF (1994) Detoxificant enzymes in pumpkin grown in polluted ambient air. J Environ Qual 23:360-364

Robison TW, Zhou H, Kim K-J (1996) Generation of glycoaldehyde from guinea pig airway epithelial monolayers exposed to nitrogen dioxide and its effect on sodium pump activity. Environ Health Perspect 104:852-856

Roitto M, Ahonen-Jonnarth U, Lamppu J, Huttunen S (1999) Apoplastic and total peroxidase activities in Scotch pine needles at subarctic polluted sites. Eur J Forest Path 29:399-410

Sandermann H Jr (1996) Ozone and plant health. Annu Rev Phytopathol 34:347-366

Sarkar RK, Banerjee, Mukherji S (1986) Acceleration of peroxidase and catalase activities in leaves of wild dicotyledonous plants, as an indication of automobile exhaust pollution. Environ Pollut 42:289-295

Sharma YK, Davis KR (1997) The effects of ozone on antioxidant responses in plants. Free Rad Biol Med 23:480-488

Tandy NC, Di Giulio RT, Richardson CJ (1989) Assay and electrophoresis of superoxide dismutase from red spruce (Picea rubens Sarg.), Loblolly pine (Pinus taeda L.), and Scotch pine (Pinus sylvestris L.). A method for biomonitoring. Plant Physiol 90:742748

Wingsle G, Hällgren JE (1993) Influence of $\mathrm{SO}_{2}$ and $\mathrm{NO}_{2}$ exposure on gluthione, superoxidase dismutase and glutathione reductase activities in Scotch pine needles. J Exp Bot 44:463-470 